\title{
Cut flower vase life - influential factors, metabolism and organic formulation
}

\begin{abstract}
Cut flowers are used to show appreciation, affection and to express emotion on various special occasions. The international trade of cut flowers has expanded in recent years and is expected to rise with the promotion and use of horticultural plants for their therapeutic benefits. Vase life quality of cut flowers is one of the most crucial factors for customer satisfaction and repeat purchase. Flowers grown for the ornamental market must be of high quality to extend cut flowers postharvest longevity and increase marketability and commercial value. Cut flowers are living actively metabolizing organs and therefore, highly perishable. Four major factors during both production and postharvest stages that influence vase life are water relations, carbohydrate status, ethylene and pathogens. The key goals of the use of many natural products such as essential oils, lemon juice, apple and fruit extracts are to find suitable alternatives to synthetic chemical vase solutions that are equally efficacious and environmentally friendly. This review highlights some of the influential factors affecting cut flower postharvest longevity, aesthetics and metabolism. The recent development and use of organic vase solutions are also highlighted.
\end{abstract}

Volume 3 Issue $6-2019$

\author{
Sanjamveer SVehniwal, Lord Abbey \\ Department of Plant, Food and Environmental Sciences, \\ Dalhousie University, Canada
}

\begin{abstract}
Correspondence: Lord Abbey, Department of Plant, Food, and Environmental Sciences, Dalhousie University, Faculty of Agriculture, 50 Pictou Road, P.O. Box 550, Truro B2N 5E3, Nova Scotia, Canada, Email loabbey@gmail.com
\end{abstract}

Received: November 08, 2019 | Published: November 18, 2019

\section{Introduction}

Postharvest techniques to achieve greater cut flower longevity must accomplish two seemingly conflicting purposes i.e. the promotion of bud growth and development of the plant part to full opening and retardation of metabolic processes leading to senescence. Many researchers have shown that an appropriate chemistry of vase solution can reduce rate of respiration and senescence and extend the longevity of cut flowers. These preservatives are composed of carbohydrates such as sugar, inhibitors of ethylene biosynthesis such as silver thiosulphate (STS) and aminoethoxyvinyl glycine and germicides e.g. 1-methylcycloproprene, chlorine dioxide and 8-hydroxyquinoline sulphate. ${ }^{1}$

The ethylene sensitivity of cut flowers drives the search for the appropriate vase solution. For instance, Carnation is an ethylenesensitive flower and if preservatives are not used its vase life is normally shortened from about 12-14 days to 7 days. ${ }^{2}$ As such, commercial carnation producers widely use STS to extend the vase life of cut flowers due to its remarkable efficacy on vase life extension. However, concern about potential heavy-metal contamination of the environment by STS waste solution has increased the search for alternative methods of controlling flower senescence in carnations. ${ }^{3}$ Most cut flower dealers have used many unorthodox substances, but the results are inconclusive. Many natural products such as essential oils, lemon juice, apple and other fruit extracts have been evaluated for vase life extension of cut flowers because they are environmentally friendly and possess antimicrobial properties. ${ }^{4}$

Compost obtained from decaying organic matter is known to have antimicrobial properties and humic substances that protect and provide nourishment to plants in many ways. ${ }^{5}$ It is therefore proposed that compost can be used a vase solution. Compost stability also defined as resistance of compost organic matter to degrade is important as immature compost may lead to depletion of oxygen or nitrogen and release of phytotoxic compounds, ${ }^{6}$ which can adversely affect cut flower if used as vase solution. This suggests that properly formulated mature and stable compost tea mixed with other natural additives can potentially be a substitute for synthetic chemical preservative solutions. This review highlights some of the influential factors affecting cut flower postharvest longevity, aesthetics and metabolism. Recent development and use of organic vase solution are also highlighted.

\section{Factors affecting vase life}

Vase life refers to the time period for which a cut flower retains its appearance in a vase. Vase life is determined based on attributes such as diameter and length of florets, the opening of flowers, changes in fresh weight, diameter or length of stem or pedicel, senescence pattern, the color of petals, total longevity and foliage folding. ${ }^{7}$ Several efforts have been directed at the evaluation of pre- and post-harvest factors affecting vase life of cut flowers some of which are described below.

\section{Preharvest conditions affecting vase life}

It has been speculated by the authors of several studies that preharvest environmental factors alter the carbohydrate status in cut flowers, which in turn affect their vase life. ${ }^{8,9}$ Despite support for this hypothesis, literature information on effects of preharvest factors on vase life of cut flowers are not comprehensive. However, previous studies on light, nutrient solution, temperature and water relations effects on cut flowers are documented. ${ }^{7,8,10}$ For instance, it is generally accepted that higher light intensity conditions help to produce optimal carbohydrate content in horticultural crops and extend flower life although effects may vary with genotype. ${ }^{11}$ Supplementary lighting and elevated carbondioxide levels have led to longer vase life in carnation (Dianthus caryophyllus), chrysanthemum (Dendranthema grandiflora) and rose (Rosa spp.) while elevated light intensity is known to affect stomatal density which in turn affects gas exchange or photosynthetic rate. ${ }^{12,13}$

In contrast to high light intensity, elevated temperatures can deplete carbohydrate reserves and decrease keeping the quality of flowers by increasing respiration rate. ${ }^{14}$ Some reports indicated that temperatures as low as $12^{\circ}-15^{\circ} \mathrm{C}$ or as high as $27^{\circ} \mathrm{C}$ during three weeks before harvest decreased the longevity of cut flowers. ${ }^{12}$ The possible interaction of temperature with other factors complicates the understanding of temperature effects on vase life. Low temperature 
can also increase pigmentation such as flavonoids and anthocyanins. ${ }^{15}$ For instance, 'Golden Wave' roses kept at low temperatures (i.e. less than $15^{\circ} \mathrm{C}$ ) developed a greenish tint. This was probably due to incomplete conversion of chloroplasts to chromoplasts, which was thought to be caused by low carbohydrate levels. It is usually assumed that if the fertility and the structure of the growing medium are within optimal range for plant growth, there will be little or no effect on the longevity of cut flowers. Another preharvest factor is salinity stress. Halevy \& Mayak ${ }^{12}$ reported that high levels of soil salinity relative to that in the plant sap will cause exosmosis and thus, reduce plant water uptake.

\section{Postharvest conditions affecting vase life}

Postharvest physiology of cut flowers deals with the functional processes in plant material after it has been harvested or removed from its natural growing environment until it is utilized or deteriorated. ${ }^{16}$ Darkness or low light intensity during shipping of cut flowers and foliage can reduce flower quality due to leaf and flower abscission. Moreover, dark-held plants stored at low temperature when moved to ambient temperatures undergo a number of stress changes such as rapid loss of chlorophyll, proteolysis, loss of catalase activity and increased membrane permeability. ${ }^{17}$

At harvest, water and materials transport in the detached plant part is interrupted leading to reduced xylem water potential below the water potential of adjacent cells. Thus, water is withdrawn from cells of the cut flower to cause shrinkage and wilting. Also, the quality of vase water is important for maintaining the vase life of cut flowers and foliage. Pure clean water with limited amounts of salt and alkalinity is a requisite. The presence of salts, basic ions, and fluoride in water reduce vase life $\mathrm{e}^{7}$ as salts and basic ions are responsible for changes in $\mathrm{pH}$ that can affect osmotic potential. ${ }^{16}$ Fluorine in water causes softening of tissues, leaf browning and wilting. It was found that addition of small amounts of fluorine (i.e. $\sim 1 \mathrm{ppm}$ ) in vase solution had injurious effects on rose cut flowers. ${ }^{18}$ Some stems of cut flowers may exude sap, various cations, anions and organic acids that can be harmful to flowers themselves, which suggested that the vase water will need regular replacement. ${ }^{16}$ Addition of cobalt ions to vase solution partially closed stomata, inhibited vascular blockage in rose stem and increased the water uptake by cut flowers. ${ }^{19}$ On the other hand, addition of magnesium and calcium ions in vase solution did not affect flower vase life.

Storage of cut flowers is economically important as it enables the producers to distribute and transport the product to its destination and to meet the demand of buyers. But an exponential increase is seen in respiration of cut flowers with an increase in storage temperature. The temperature outside the physiological norm can cause damage to cut flowers by freezing injury that results in the immediate collapse of tissue or by heat injury that can heat up tissues above the thermal cell death point. ${ }^{16}$ Cooling prior to packaging and transportation reduces metabolic changes such as enzymatic activity, slows down the maturation of flowers, and reduces ethylene production, metabolic processes and improves longevity. ${ }^{7}$ The close association of flower respiration during storage and vase life suggest the potential use of controlled atmosphere technology to extend vase life. ${ }^{20}$ There are two controlled systems i.e. modified atmosphere packaging (MAP) and controlled atmosphere packaging (CAP) systems. Cut flowers and foliage can be enclosed in a gas impermeable package to create an inside environment that can modify carbon dioxide, oxygen, nitrogen, water vapor and trace gases. To provide an optimum atmosphere for increasing the storage length and quality of produce, a MAP is created by altering the normal composition of air (i.e. $78 \%$ nitrogen, $21 \%$ oxygen, $0.03 \%$ carbon dioxide and traces of noble gases). Under CAP conditions, the atmosphere is modified from that of the ambient atmosphere, and these conditions are maintained throughout the storage duration. MAP uses the same principles as CAP. However, it is used on smaller quantities of cut flowers and the atmosphere is only initially modified. MAP and CAP for packaging fresh cut products reduce polyphenol oxidase and ethylene production and reduced amount of oxygen and elevated carbon dioxide reduces respiration..$^{21}$ However, oxygen concentration below a critical level for supporting aerobic respiration may result in the glycolytic conversion of pyruvate into acetaldehyde and ethanol, which leads to tissue fermentation and browning. ${ }^{22}$

Many postharvest diseases such as botrytis rot, mildews and other molds affect cut flowers. The wounded stem-end quickly depletes oxygen in the vase solution due to the increased rate of cellular respiration, which also provide perfect growing conditions for microbes. ${ }^{23}$ Microbial cells are responsible for plugging the vascular system, enzymatic damage to vascular tissue, disruption of cell membrane integrity by releasing toxic metabolites and enhance the production of ethylene. ${ }^{23}$

\section{Ethylene and flower longevity \\ Role of ethylene in senescence}

The Role of endogenous ethylene in triggering petal senescence is well known. ${ }^{23}$ Flowers can be classified as climacteric or nonclimacteric based on ethylene sensitivity that can vary from one species to another. In carnation, it is observed that ethylene is first produced in the pistil and then acts on the petals. This induces the expression of genes for ACC synthase, ACC oxidase and cysteine proteinase resulting in auto-catalytic ethylene production. The physical signs of ethylene response include in-rolling of the petals and wilting of flowers.

\section{Ethylene biosynthesis}

Ethylene biosynthesis is under strict metabolic pathway. The sequence of the pathway of ethylene biosynthesis is defined as methionine $\rightarrow$ S-adenosyl methionine $(\mathrm{SAM}) \rightarrow 1$-aminocyclopropane -1-carboxylic acid (ACC) $\rightarrow$ ethylene. It was observed that ACC content was very low in freshly harvested cut carnation flowers, but it rose rapidly with the onset of senescence. ${ }^{24}$ The lifespan of cut flowers is often terminated by the abscission of petals or by petal wilting. In many species, these processes are regulated by ethylene through changes in endogenous levels. Ethylene production changes during plant development and in relation to physiological status. ${ }^{24}$ Ethylene production is induced during certain critical stages of growth such as abscission of leaves and senescence of flowers along with other external factors such as mechanical wounding, environmental stress and certain chemicals like auxins.

\section{Metabolic changes in cut flowers}

\section{Wounding and emboli formation}

Suberization is the general response to mechanical damage of plant tissue in which a hydrophobic polymeric material called suberin attaches to cell walls. Suberin can be found in intercellular spaces between xylem parenchyma cells adjacent to wounded vessels and 
is responsible for compartmentalization after wounding. As such, suberization can be a barrier to water uptake. Upon cutting off a stem, water column in plants breaks resulting in the drawing of air into xylem vessels which constricts water flow in the xylem. Also, plant tissue blockage termed as emboli is formed immediately upon cutting the stem. Emboli result in a temporary reduction in water uptake but may become permanent if the rate of transpiration exceeds the water conductance of the wounded stem. ${ }^{20}$ The reversion of air emboli present in xylem vessels partly results in a positive water balance and restoration of water uptake after harvest of cut flowers and foliage. ${ }^{25}$ The use of techniques such as detergent dips or vase solutions, low $\mathrm{pH}$, re-cutting of the stem under water and immersing the stem in deep water containing biocide may help in improving rehydration and the vase life of recalcitrant cut flowers like Heliconia (Heliconia rostrate). ${ }^{20}$

\section{Water balance and weight change}

The most common cause of short vase life in cut flowers was found to be water stress following the termination of steady flow of water at harvest. Undesirable appearance and short vase life of cut flowers may result from reduced water uptake by xylem blockage due to microbial growth, deposition of gum and mucilage in the lumen of xylem vessels and the presence of air emboli in vascular tissues. ${ }^{16}$ This can cause competition for water among the various tissues in the cut flower tissues. Water imbalance due to continuous loss of water through transpiration may result in drooping and pre-mature wilting of flowers making them unacceptable to consumers. Thus, the appropriate water balance and turgor level, for example, are necessary for the development of buds to bloom. Water loss also enhances premature ripening, senescence, browning, chilling injury and thus, limits the vase life of cut flowers and foliage. More importantly, the vase life of cut flowers is determined by the rate of transpiration through stomata and the type and nature of the solutes present in the vase solution. It is generally known that the sugar in vase solution helps to reduce transpiration rate.

\section{Senescence and abscission}

The cells of senescing organs undergo gradual and orderly disassembly. ${ }^{15}$ Plant growth hormones, especially cytokinin appear to control the monocarpic senescence process. Ethylene is known to stimulate changes in membrane lipids of leaves and petals, which results in the rolling of petals, drying of sepals and corollas, wilting of flower and change in color. Earlier, van Doorn \& Stead ${ }^{26}$ reported increased protease activity and respiration, and reduced lipid fluidity of membranes in petals of cut flowers undergoing senescence. On the stem of cut flowers, there are several leaves that also suffer the degenerative process of senescence. These reports suggested that leaf senescence leads to several metabolic changes including increased activity of protease, nucleases and chlorophyllases; and can be triggered by stressful conditions such as high salinity, low light conditions and removal of roots.

\section{Cellular leakage}

Two major metabolic and biochemical changes that occur in senescing petals are increases in respiration and hydrolysis of cell components. ${ }^{7}$ Respiration mediates the release of for example energy, oxidative breakdown of carbon compounds, synthesis and degradation of carbohydrates, proteins, lipids, organic acids, vitamins and pigments. ${ }^{16}$ Most of these occurrences are undesirable to the cut flower.
Cell hydrolysis includes membrane rupturing, increase in cytoplasmic debris, invagination of tonoplast, endocytosis of cytoplasmic contents, the disappearance of microtubules, reduction in cytoplasmic volume, and change in proton flux across the plasma membrane and increase in peroxisomes. ${ }^{7}$ These lead to a dramatic increase in the leakage of several cellular molecules including amino acids, sugars, inorganic ions and anthocyanins in addition to an increase in the activity of petal 1-ACC synthetase, which is a precursor for ethylene production, and the disintegration of tonoplast and mitochondria.

\section{Change in flower color}

Carotenoids constitute yellow, orange and red pigments whereas anthocyanins and other related compounds are responsible for the red, purple and blue coloration of plant tissues. Anthocyanins often mask carotenoids and chlorophyll and are red at acidic $\mathrm{pH}$ and blue at basic $\mathrm{pH}$. This gives rise to a phenomenon called 'blueing' that results in a shift of coloration to blue with aging due to depletion of sugars. Cellular $\mathrm{pH}$ is important in the regulation of metabolism, and due to the presence of large vacuoles, usually, the cellular $\mathrm{pH}$ is highly acidic (i.e. $<5$ ). To maintain cytoplasmic $\mathrm{pH}$, metabolic processes consume or produce protons in the plasmalemma and in the tonoplast. ${ }^{27}$ In senescing petals, disassembly of chloroplasts is a programmed process and thylakoid proteins are immobilized. Thus, loss of photosynthetic activity of cells begins with the orderly disassembly of thylakoids.

\section{Role of carbohydrates in vase solution}

Carbohydrates have numerous roles in plants i.e. serving as photosynthetic precursors required for growth, respirable substrates, osmoregulators and sometimes as osmoprotectants. Additionally, carbohydrates can act as cellular signals by controlling gene expressions. Sugar added to vase solution is also known to extend the vase life in several cut flowers as it helps to maintain the respiration rate of floral tissues. ${ }^{16}$ Sugar content in plant organs change throughout plant development and some plant organs such as developing flowers act as a sink. With the cutting of a stem, there is a complete reduction of sucrose import to sink tissues of cut flowers. This leads to the alteration of carbohydrate metabolism. Hence, the use of sucrose in the vase solution has a significant effect on the physiological status of floral tissues and the endogenous levels of sucrose. As such, the addition of sucrose helps in accelerating flower opening and delay flower senescence. Sucrose addition to vase solution was followed by an increase in the length of inflorescence, opening of flower heads and prolonging of the vase life of spikes of Liatris spicata (L.) Willd. ${ }^{28}$ It was observed that sucrose did not extend the vase life by improving solution uptake but by delaying senescence. Despite the importance of sucrose as a substrate for respiration and as an osmolyte, other sugars and sugar alcohols (or polyols), including raffinose, trehalose, mannitol and sorbitol have the added function of protecting plants from stress. ${ }^{29}$ The polyols mannitol and sorbitol have two crucial functions. They act as both osmotic adjusters and protective compounds. Therefore, it is believed that these sugars and polyols could be beneficial when added to vase solutions or used as pulse treatments following the harvest of cut flowers. Studies with vegetative cuttings indicated that higher levels of endogenous carbohydrates reduce sensitivity to ethylene, but do not reduce ethylene production..$^{30}$ Therefore, in cut flowers, increased endogenous carbohydrates may not only increase vase life by increasing respirable substrate but might also decrease ethylene sensitivity. 


\section{Compost}

Composting is the biological decomposition and stabilization of organic substrates. During the aerobic composting process, the elevated temperature at the thermophilic stage sterilizes the final compost product by making it free of pathogens and plant seeds. ${ }^{31}$ The products of aerobic composting are mainly carbon dioxide, water and heat whereas the products of anaerobic decomposition are mostly methane, carbon dioxide and low molecular weight organic acids and alcohols. ${ }^{31}$ Application of compost is known to reduce weeds and fungal diseases in crop production systems. Brown and Tworkoski reported that growth of the brown rot fungus (Monilinia fructicola) was significantly slower on compost substrate. Stable compost can reduce plant pathogens and improve plant resistance to diseases. It also contains valuable nutrients like nitrogen, phosphorus and other essential micronutrients. ${ }^{31}$ The properties of compost are known to vary according to the feedstock used and the process of preparation of the compost. But compost formulation as a vase solution for cut flowers has rarely been reported in the literature.

\section{Compost as replacement of synthetic chemical vase solution}

Compost is known to supply nutrients as well as beneficial organic compounds to plants. Compost is rich in biomass of microorganisms and high contents of total extractable nutrients (16 mg nitrogen/g, $9 \mathrm{mg}$ phosphorus/g and similar levels for most other nutrients). ${ }^{32}$ Several organic and inorganic substances such as humic acid, sugar, and amino acids are present in compost extracts and these promote plant growth. Compost tea is recently being used to control various plants diseases such as rose (Rosa spp.) powdery mildew, grape (Vitis vinifera) mildew, leaf anthracnose, peach (Prunus persica) leaf curl, cherry (Prunus cerasus) brown rot and apple (Malus pumila) scab. The exact mechanism is unknown, but it is thought that compost tea contains antibiotic compounds that suppress these plant pathogens. ${ }^{33}$

Humic acids are a mixture of naturally occurring organic compounds present in composts, soils, natural waters and sediments and are generally derived from the decomposition of animal and plant residues. Humic acids promote plant chlorophyll content and photosynthesis. ${ }^{34}$ Humic substances serve as energy source for beneficial soil organisms, which release complex polysaccharides (i.e. sugar based compounds). These compounds help in the improvement of carbohydrate contents of plants and can thus, influence the quality and life of cut flowers. This is because the postharvest life of cut flowers has been shown to be dependent on the carbohydrate status of the flowers. ${ }^{16}$ Humic acids influence antioxidative defense mechanisms by stimulating catalases (CAT) to improve the postharvest quality of cut flowers. This agreed to observation made by Fan et al..$^{35}$ who demonstrated that foliar application of humic acids increased chlorophyll content, rate of photosynthesis, flower size and flower fresh weight.

\section{Carbohydrates in compost}

Organic matter has been reported to contain organic materials such as lignin, proteins, lipids, cellulose and non-cellulosic carbohydrates (hemicellulose, starch, and mono- and oligosaccharides) that are metabolized along different pathways. ${ }^{36}$ Presence of hydrolyzable carbohydrates (acidic and neutral) has been reported in compost. Hexose carbohydrates constituted the largest proportion of neutral sugars with glucose being the most abundant. ${ }^{37}$ It was also reported that the proportion of acidic sugars to total carbohydrates was higher in well-cured compost. The number of hexoses and pentoses in compost feedstock samples and humic and fulvic acids were reduced during the composting process. D-glucitol was the main sugar alcohol in compost but its relative amount decreased during composting while the amounts of all the other sugar alcohols increased. The compost of these carbohydrates in vase solution may influence cut flower vase life.

\section{Pathogens in compost}

It is presupposed that well degraded, mature and cured compost does not contain any harmful microbial populations. However, an ecotoxicological tests will be required to ascertain compost safety, especially when used as a vase solution in households. Pathogen control and degradation of toxic organic compounds by composting are important public health measures. It is assumed that during the composting process when the temperature rises between $45^{\circ}$ to $70^{\circ} \mathrm{C}$, most of the bacterial pathogens and weed seeds are killed. However, the compost must be pathogen free to ensure profitable use of the product. A major concern is the potential for human pathogens to grow in the compost tea.

\section{Compost amendment of growing medium to enhance vase life of cut flowers}

Several experiments have been conducted using compost, which indirectly indicated that compost can improve the vase life of cut flowers. Compost has been used during the growth stages of flowers to increase the vase life of cut flowers. ${ }^{35}$ A study was carried out using different combinations of farmyard manure, poultry manure, sand, leaf compost and coconut coir in equal proportions to determine their effects on the morphological parameters and vase life of tuberose (Polianthes tuberosa). The highest values of floral diameter, number of flowers per spike and shelf life were recorded for the combined sand and leaf compost medium. ${ }^{38}$ These components gave better quality cut flower production with maximum vase life compared to all the other medium treatments. Postharvest vase life was also studied by applying foliar humic acid fertilizer extracted from compost to chrysanthemum flowers. Seedlings of chrysanthemum were sprayed with equal volumes of distilled water, inorganic compound fertilizer (i.e. nitrogen-phosphorus-potassium (NPK) at 16:6:20 (\%)) and organic foliar humic acid (FHA) fertilizer every 15 days. Application of FHA resulted in increased chlorophyll content, photosynthesis rate, soluble sugars and soluble proteins in leaves of chrysanthemum. ${ }^{35}$ Also, there was an increase in vase life, flower size and fresh weight of cut chrysanthemum flowers. The vase life was $61 \%$ and $33 \%$ greater in humic acid spray than in distilled water and NPK treatment, respectively. Another similar experiment also showed that $1.25 \mathrm{ml}$ FHA $(8 \%)+10 \mathrm{~g} / \mathrm{m}^{2}$ NPK $(17: 17: 17)$ under greenhouse conditions increased vegetative growth, flower production and vase life of tulip (Tulip sp.) 'Triumph'.2 Tamrakar ${ }^{39}$ revealed that treatments of vermiwash, cow urine, and $\mathrm{GA}_{3}$ have a significant effect on vegetative growth, flowering and vase life of gladiolus (Gladiolus grandiflorus) 'Candyman'. These showed that water extract of compost tea may have the potential to extend the vase life of cut flowers, but detailed investigation is required prior to recommendation.

\section{Potential of compost tea as vase solution}

Compost tea is a water extract of matured and well cured compost that has been used for centuries since the Roman Empire..$^{40}$ Compost tea is a sustainable, economic and feasible way to efficiently utilize nutrients in compost. It is rich in nutrients and beneficial microbial 
communities and prepared in an oxygenated environment. Anaerobic conditions are minimized to avoid the production of organic acids, which are detrimental to plants. There is growing interest in the use of compost tea in integrated pest management as it inhibits several diseases due to the presence of high concentration of beneficial microorganisms..$^{41}$ It is well acknowledged that compost tea has the potential to supplement the use of synthetic chemical pesticides with many environmental, health and economic benefits. Compost tea contains many microbial communities that enhance plant growth and suppress disease-causing pathogens including bacteria (Bacillus), yeasts (Sporobolomyces and Cryptococcus) and fungi (Trichoderma) as well as chemical antagonists such as phenols and amino acids. Compost tea can be tailored for its desired use. For example, a compost tea can be specifically brewed for use as soil organic matter builder, a disease suppressant, or a nutrient source. ${ }^{40}$

\section{Mechanism of action of compost tea}

Compost acts as a food source for the antagonists that compete with plant pathogens. The mechanism by which compost tea works is not well understood but seems to depend on host-pathogen interaction and mode of application. ${ }^{41}$ These biological interactions are complex and can happen through the following non-exclusive mechanisms:

Antibiosis: It is an antagonistic association between two organisms in which one is adversely affected. Some beneficial organisms can produce compounds that inhibit the growth of disease-causing organisms by producing antibiotics toxic to them. ${ }^{40}$ For example, bacteria Pseudomonas fluorescens strain $\mathrm{CHAO}$ produces hydrogen cyanide, 2,4-diacetyl phloroglucinol, and pyoluteorin which directly interfere with the growth of various pathogens, ${ }^{42}$

Competition: when beneficial microorganisms are present in a growing medium they tend to out-compete pathogenic bacteria or fungi for food sources and infection sites leaving no food for diseasecausing organisms. ${ }^{40}$ Even if the disease-causing organisms start to grow, they cannot penetrate the tissues of the plant;

Induced resistance: some beneficial microbes colonizing plant roots or foliage confer resistance to a plant by turning on plant genes that increase the plant tolerance to infection by pathogens; ${ }^{42}$

Parasitism: certain beneficial microbes can feed on specific pathogens, for example, Trichoderma species have been shown in numerous studies to secrete enzymes that digest the cell wall of some fungal root pathogens; ${ }^{40}$

Nutrients: compost tea also contains soluble nutrients that perform different key functions. These nutrients feed the beneficial organisms that already exist within the compost tea, so they grow faster and are healthier and can perform disease suppressive functions. They also help in retaining the nutrients in the medium for plant uptake.

\section{Organic substances used to extend vase life}

\section{Germicides}

Synthetic germicides such as silver nitrate $\left(\mathrm{AgNO}_{3}\right)$ and 8-hydroxyquinoline citrate (8-HQC) improve water uptake by preventing the blockage of xylem vessels. ${ }^{43}$ Organic antimicrobial compounds have been reported as an alternative biocide for the floriculture industry. Malic acid along with sucrose proved to be effective in controlling bacterial population in vase life preservative solution. This also limits ACC-oxidase activity in cut carnation flowers. Antimicrobial compounds were found in methanolic and ethanolic leaf extracts of Jatropha curcas, Andrographis paniculata, and Psidium guajava. These were found to be effective against microbes in vase solution of cut Mokara Red orchid flowers. The solution with leaf extract of $A$. paniculata had the lowest bacterial count compared to the other extracts. Thus, the leaf extracts can serve as a potential solution to reduce the microbial population and can be potentially utilized to extend the vase life of flowers. ${ }^{43}$

\section{Acidifiers}

A major cause of reduction of vase life in flowers is water flow interruption due to microbial proliferation. Acidifying agent such as citric acid is used to lower the $\mathrm{pH}$ of vase solution. Citric acid was reported to increase the vase life and the fresh weight of cut roses. In chrysanthemum, the application of citric acid increased vase life, petal water content, initial fresh weight, and marketable value. Thus, citric acid can be used as a natural, cheap, safe and biodegradable compound that can be efficiently used as an alternative to synthetic treatments to prolong vase life of cut flowers. ${ }^{44}$ Sucrose treatment alone without germicides promoted bacterial proliferation and led to a shortening of vase life. However, the addition of citric acid was effective as an antimicrobial compound and was readily and inexpensively obtained from lemons, lime and oranges. Also, salicylic acid proved to increase chrysanthemum initial fresh weight, leaf relative water content and petal water content by 23,49 and $73 \%$ respectively, as compared to the controls. ${ }^{44}$ At a concentration of $300 \mathrm{ppm}$, salicylic acid remarkably increased chrysanthemum vase life to 22 days. Salicylic acid extension of vase life was attributed to its plant regulation and anti-stress properties. The effect of pre- and post-harvest application of salicylic acid was also reported by Soleimany-Fard et al..$^{45}$ on cut alstroemeria (Alstroemeria sp.) flowers. About $3.0 \mathrm{mM}$ salicylic acid improved the vase life, fresh weight, water uptake, water balance, total chlorophyll content, and suppressed water loss in alstroemeria 'Tampa' compared to control (distilled water) treatment.

\section{Coagulants}

Potassium aluminum sulfate (alum) has proved to be an effective coagulant that prolongs the vase life and increase the final weight of Sampaguita flower (Jasminum sambac). Alum is synthetic sulphate salt of aluminum and excess use can result in some negative impacts caused by aluminum. There are several other organic coagulants available like polyamines and melamine. However, literature information pertaining to their use for cut flower vase life extension is limited.

\section{Hormones and growth regulators}

Several growth regulators and hormones are known to extend the postharvest life of different flowers. Kinetin is known to increase water uptake and petal growth in leafless flower shoots of cut roses. It also maintained petal turgidity for an extended period. ${ }^{8}$ Gibberellins are also important growth regulators that increase the postharvest quality of cut flowering shoots of Alstroemeria, Euphorbia fulgens and Narcissus tazetta. ${ }^{46}$ Methyl jasmonate also improved the vase life and size of fresh cut Peony (Paeonia officinalis) flowers.

\section{Herbal extracts}

Various herbal extracts like piper (Piper magnificum), Annona (Annona reticulata), curcuma (Curcuma longa), tobacco (Nicotiana tabacum) and galangal (Alpinia galangal) are also known to control microbes isolated from the holding solutions of cut roses. Piper 
extracts at $0-10 \%(\mathrm{w} / \mathrm{v})$ concentrations showed complete inhibition of microbial growth in vase solutions, delayed bent neck, reduced ethylene production and maintained freshness of leaves. ${ }^{47}$ Essential oils are organic, safe, environmentally friendly and contain biodegradable compounds and have been proved to be the most suitable alternative for the prolongation of vase life in several cut flowers. Trials were conducted on carnation to determine the effects of essential oils from thyme (Thymus vulgaris L.), summer savory (Satureja hortensis L.) and ajwain (Carum copticum L.). It was observed that all the extracted oils prolonged carnation vase life. Summer savory oil showed the highest effect by increasing the fresh weight to almost $100 \%$ in comparison to distilled water used as a control. Another nine essential oils extracted from anise (Pimpinella anisum), cumin (Cuminum cyminum), geranium (Pelargonium graveolens), common lavender (Lavandula angustifolia), sage (Salvia officinalis), sweet basil (Ocimum basilicum), cinnamon (Cinnamomum zeylanicum), blue gum (Eucalyptus globulus) and lemon grass (Cymbopogon flexuosus) were tested for their antimicrobial effects on the vase life of cut roses by Shanan. ${ }^{48}$ The study indicated that lavender, geranium and anise increased vase life, fresh weight and water uptake in addition reducing transpiration. They suppressed blockage of xylem vessels by reducing bacteria and fungi growth in the vase solution. Babarabie et al. ${ }^{49}$ studied rosemary essence along with cola, peppermint and apple extract and were found to be effective as natural ingredients for cut flower preservation.

\section{Conclusion}

Though compost tea has been widely used to control diseases in several field crops the use of compost tea for vase life extension of cut flowers has not been widely evaluated. The possible utilization of compost tea and other natural substances for vase life extension is attracting several researchers. There is a good understanding of various aspects of flower senescence in common cut flowers such as rose, carnation and chrysanthemum. However, many practical problems have not been solved yet. The properties and composition of compost tea and the effect of natural substances on vase life extension still need to be adequately investigated prior to recommendation.

\section{Acknowledgments}

None.

\section{Conflicts of interests}

Authors declare no conflict of interest exists.

\section{References}

1. Elhindi, KM. Evaluation of several holding solutions for prolonging vase-life and keeping quality of cut sweet pea flowers (Lathyrus odoratus L.). Saudi Journal of Biological Sciences. 2012;19(2):195-202.

2. Ali A, Rehman SU, Raza S, et al. Combined effect of humic acid and NPK on growth and flower development of Tulipa gesneriana in Faisalabad, Pakistan. International Journal of Agro Veterinary and Medical Sciences. 2014; 9(1):18-28.

3. Mijnendonckx K, Leys N, Mahillon J, et al. Antimicrobial silver: uses, toxicity and potential for resistance. Biometals. 2013;26(4):609-621.

4. El-Moneim AA, Abdel-Fattah G, Khenizy S. Effect of natural extracts on vase life of gypsophila cut flowers. Scientific Journal of Flowers and Ornamental Plants. 2018;1(1):1-16.
5. Steel H, Moens T, Vandecasteele B, et al. Factors influencing the nematode community during composting and nematode-based criteria for compost maturity. Ecological Indicators. 2018;85:409-421.

6. Raviv M. Production of high-quality composts for horticultural purposes: a mini-review. HortTechnology. 2005;15(1):52-57.

7. De LC, Deb P, Chhetri G, et al. Pre-and post-harvest physiology of Cymbidium orchids. International Journal of Horticulture. 2015;5(6):15.

8. Halevy AH, Mayak S. Senescence and postharvest physiology of cut flowers, part 1. Horticultural Reviews. 1979;1:204-236.

9. Fanourakis, D, Pieruschka R, Savvides A, et al. Sources of vase life variation in cut roses: a review. Postharvest Biology and Technology. 2013;78:1-15.

10. Rafdi HHM, Joyce DC, Lisle A, et al. A retrospective study of vase life determinants for cut Acacia holosericea foliage. Scientia Horticulturae. 2014;180:254-261.

11. Pettersen RI, Torre S, Gislerød HR. Effects of intracanopy lighting on photosynthetic characteristics in cucumber. Scientia Horticulturae. 2010;125(2):77-81.

12. Mayak S, Halevy AH. Interrelationships of ethylene and abscisic acid in the control of rose petal senescence. Plant Physiology. 1972;50(3):341346.

13. Naing AH, Jeon SM, Park JS, et al. Combined effects of supplementary light and $\mathrm{CO} 2$ on rose growth and the production of good quality cut flowers. Canadian Journal of Plant Science. 2016;96(3)|:503-510.

14. Locke EL. Extending cut flower vase life by optimizing carbohydrate status: preharvest conditions and preservative solution, $\mathrm{PhD}$ thesis, North Carolina State University. 2010.

15. Rani P, Singh N. Senescence and postharvest studies of cut flowers: a critical review. Pertanika Journal of Tropical Agricultural Science. 2014;37(2):159-201.

16. Da Silva JAT. The cut flower: postharvest considerations. Journal of Biological Sciences. 2003;3(4):406-442.

17. Ranwala AP, Miller WB. Effects of cold storage on postharvest leaf and flower quality of potted Oriental-, Asiatic-and LA-hybrid lily cultivars. Scientia Horticulturae. 2005;105(3):383-392.

18. Lohr VI, Pearson-Mires CH. Damage to cut roses from fluoride in keeping solutions varies with cultivar. HortScience. 1990;25(2):215-216.

19. Singh PV, Sharma M. The postharvest life of pulsed gladiolus spikes: the effect of preservative solutions. Elegant Science in Floriculture. 2002;624:389-398.

20. Reid MS, Jiang CZ. Postharvest biology and technology of cut flowers and potted plants. Horticultural Reviews. 2012;40:1-54.

21. Tian S, Xu Y, Jiang A, et al. Physiological and quality responses of longan fruit to high $\mathrm{O} 2$ or high $\mathrm{CO} 2$ atmospheres in storage. Postharvest Biology and Technology. 2002;24(3):335-340.

22. Gran CD, Beaudry RM. Determination of the low oxygen limit for several commercial apple cultivars by respiratory quotient breakpoint. Postharvest Biology and Technology. 1993;3(3):259-267.

23. Reid MS. Postharvest handling systems: ornamental crops. Postharvest Technology of Horticultural Crops. 2002;315-325.

24. Yang SF, Hoffman NE. Ethylene biosynthesis and its regulation in higher plants. Annual Review of Plant Physiology. 1984; 35(1):155-189. 
25. van Meeteren U, van Gelder A. Should we reconsider the use of deionized water as control vase solutions?. VII International Symposium on Postharvest Physiology of Ornamental Plants. 1999;543:257-264.

26. van Doorn WG, Stead AD. Abscission of flowers and floral parts. Journal of Experimental Botany. 1997;48(4):821-837.

27. Winkel-Shirley B. Flavonoid biosynthesis. A colorful model for genetics, biochemistry, cell biology, and biotechnology. Plant Physiology. 2001;126(2):485-493.

28. Han SS. Role of sucrose in bud development and vase life of cut Liatris spicata (L.) Willd. HortScience. 1992;27(11):1198-1200.

29. Bohnert HJ, Nelson DE, Jensen RG. Adaptations to environmental stresses. The plant cell. 1995;7(7):1099.

30. Rapaka VK, Faust JE, Dole JM, et al. Diurnal carbohydrate dynamics affect postharvest ethylene responsiveness in portulaca (Portulaca grandiflora 'Yubi Deep Rose') unrooted cuttings. Postharvest Biology and Technology. 2007;44(3):293-299.

31. Haug R. The practical handbook of compost engineering. Routledge. 2018 .

32. Ingham ER. Brewing compost tea. Kitchen Gardener. 2000;29:16-19.

33. Lanthier M. Compost tea and its impact on plant diseases. BC Organic Grower. 2007;10(2):8-11.

34. El-Ghamry AM, El-Hai KA, Ghoneem KM, et al. Amino and humic acids promote growth, yield and disease resistance of faba bean cultivated in clayey soil. Australia Journal of Basic and Applied Science. 2009;3(2):731-739.

35. Fan HM, Li T, Sun X, et al. Effects of humic acid derived from sediments on the postharvest vase life extension in cut chrysanthemum flowers Postharvest Biology and Technology. 2015;101:82-87.

36. Said-Pullicino D, Erriquens FG, Gigliotti G. Changes in the chemical characteristics of water-extractable organic matter during composting and their influence on compost stability and maturity. Bioresource Technology. 2007a;98(9):1822-1831.

37. Said-Pullicino D, Kaiser K, Guggenberger G, et al. Changes in the chemical composition of water-extractable organic matter during composting: distribution between stable and labile organic matter pools, Chemosphere. 2007b;66(11):2166-2176.
38. Ikram S, Habib U, Khalid N, et al. Effect of different potting media combinations on growth and vase life of Tuberose (Polianthes Tuberosa Linn.). Pakistan Journal of Agriultural Science. 2012;49(2):121-125.

39. Tamrakar SK. Effect of plant growth regulators, vermiwash and cow urine on vegetative growth, flowering, corm production and vase life of gladiolus var. Candyman, $\mathrm{PhD}$ thesis, Indira Gandhi Krishi Vishwavidyalaya, Raipur. 2016.

40. Ingham E, Alms M. Compost tea soil food web Incorporated. 2003.

41. Ghorbani R, Wilcockson S, Koocheki A, et al. Soil management for sustainable crop disease control: a review. Environmental Chemistry Letters. 2008;6(3):149-162.

42. Haas D. Défago G. Biological control of soil-borne pathogens by fluorescent pseudomonads. Nature Reviews Microbiology. 2005;3(4):307-319.

43. Rahman MM, Ahmad SH, Mohamed MTM, et al. Antimicrobial compounds from leaf extracts of Jatropha curcas, Psidium guajava, and Andrographis paniculata. The Scientific World Journal. 2014;14:635240.

44. Vahdati Mashhadian N, Tehranifar A, Bayat H, et al. Salicylic and citric acid treatments improve the vase life of cut chrysanthemum flowers. Journal of Agricultural Science and Technology. 2012;14(4):879-887.

45. Soleimany-Fard E, Hemmati K, Khalighi A. Improving the keeping quality and vase life of cut alstroemeria flowers by pre-and post-harvest salicylic acid treatments. Notulae Scientia Biologicae. 2013;5(3):364.

46. Ichimura K, Goto R. Extension of vase life of cut Narcissus tazetta var. chinensis flowers by combined treatment with STS and gibberellin A3. Journal of the Japanese Society for Horticultural Science. 2002;71(2):226-230.

47. Jitareerat $\mathrm{P}$, Ruenroengklin N, Uthairatanakij A, et al. Use of herba extracts for inhibiting microbial growth in holding solutions of cut-rose. Acta Horticulture. 2007;804:291-296.

48. Shanan N. Application of essential oils to prolong the vase life of rose (Rosa hybrid L. cv. 'Grand') cut flowers. Journal of Horticultural Science and Ornamental Plants. 2012;4(1):66-74.

49. Babarabie M, Zarei H, Varasteh F. Potential of increasing the vase life and improvement of some physiological characteristics of Alstroemeria cut flowers by using non-harmful compounds environmentally. Journal of Chemical Health Risks. 2016;6(1):1-8. 